\section{New Jersey Farm Soil Copper Levels Resulting from Copper Fungicide Applications}

\author{
Meredith V. Melendez ${ }^{1}$, Joseph R. Heckman², \\ Stephanie Murphy ${ }^{3}$, and Frank D’Amico ${ }^{4}$
}

AdDITIONAL INDEX WORDs. fertility, Lactuca saitiva, organic, pesticide, toxicity

SUMMARY. Vegetable growers have expressed concerns regarding the accumulation of copper in soil where copper-based fungicides are used and have requested guidance for copper pesticide applications. Elevated soil copper levels have the potential to become toxic to sensitive crops and impact soil health. In response, total and available soil copper levels were surveyed using soil analysis of samples from 15 New Jersey farms representing organic and conventional production methods. Lettuce (Lactuca sativa) was grown in the sampled soil in a greenhouse trial and evaluated for signs of copper toxicity. We found that all 15 farms were using copper fungicide preventative sprays during the previous 2 years. The soil copper levels of these farms were higher in copper-applied soils than the corresponding noncopperapplied soil. Soil copper levels were not near or in excess of established clean-up limits at any of the locations. Greenhouse-grown lettuce in the sampled soils was not negatively impacted by the copper levels. Due to the increase in the total and soluble soil copper levels, growers should use best management practices to prevent the accumulation of excessive amounts of copper in the soil over time.

$\mathrm{F}$ ruit and vegetable growers have historically relied on copperbased fungicides for disease prevention and suppression. Elevated disease pressure on tomato (Solanum lycopersicum) from late blight (Phytophthora infestans) has increased the need for preventive fungicides for organic growers. There are limited options for organic growers that have proven efficacy. During visits to New Jersey farms, organic growers expressed concerns that their use of copper fungicides might be increasing soil copper levels, thus reducing the beneficial microbial populations in the soil and potentially limiting crop growth. In New Jersey, the sampled farms during this study

Received for publication 29 Aug. 2019. Accepted for publication $10 \mathrm{Feb} .2020$.

Published online 6 March 2020.

${ }^{1}$ Department of Agriculture and Natural Resources, Rutgers, The State University of New Jersey, 1440 Parkside Avenue, Ewing, NJ 08638

${ }^{2}$ Department of Plant Biology and Pathology, Rutgers, The State University of New Jersey, 59 Dudley Road, New Brunswick, NJ 08901

${ }^{3}$ Rutgers Soil Testing Laboratory, Rutgers, The State University of New Jersey, 57 US Highway 1, New Brunswick, NJ 08901

${ }^{4}$ Research and Technology Center, FMC Agricultural Solutions, 1090 Elkton Road, Newark, DE 19711

M.V.M. is the corresponding author. E-mail: melendez@ njaes.rutgers.edu.

This is an open access article distributed under the $\mathrm{CC}$ BY-NC-ND license (https://creativecommons.org/ licenses/by-nc-nd/4.0/).

https://doi.org/10.21273/HORTTECH04494-19 most commonly used the following copper fungicides for tomato: cuprous oxide (Nordox 75 WP; Nordox, Oslo, Norway); copper hydroxide (Champ WG; Newfarm, Alsip, IL); and copper hydroxide (Nu-Cop 50; Albaugh, Ankeny, IA). Usage of cuprous oxide and copper hydroxide involves various maximum annual application rates, resulting in farms applying varying amounts of total copper to their fields based on the product they are using (Table 1). Farm copper inputs are not limited to fungicide applications. Copper is a common component of animal feeds because it is a required dietary mineral. Animal manures can serve as a source of copper where grazing takes place and when animal manures are applied to production areas. The National Research Council (1994) currently recommends that the concentration of copper as a trace mineral in turkey feed should be 4 to $8 \mathrm{mg} \cdot \mathrm{kg}^{-1}$. A study of poultry manure application on fields producing cotton (Gossypium hirsutum) and corn (Zea mays) was conducted in the southeastern United States over a 10year period. Researchers found that the manure application rate was a critical factor in the levels of soil copper in depths of 0 to $15 \mathrm{~cm}$ (He et al., 2009). Another study performed in the southeastern United States evaluated poultry litter application to welldrained soils over a 14-year period and found that the total copper concentrations were significantly greater than those of untreated soils at soil depths of 0 to $2.5 \mathrm{~cm}$ and 2.5 to 7.5 $\mathrm{cm}$ (Ashjaei et al., 2011). Many farms use rotational grazing of livestock and use animal manures as soil amendments to improve their soil quality. The U.S. Department of Agriculture (2000) suggests a soil $\mathrm{pH}$ of 6.5 or higher to reduce the availability of copper to plants consumed by humans and animals. Additionally, soils with organic matter content more than $10 \%$ will sequester copper ions, thereby reducing the availability to plants (Evans et al., 2007). This sequestration of copper ions increases the total soil copper levels and can serve as a copper sink with the potential to become available due to changing soil variables. The New York Department of Environmental Conservation and New York State Department of Health (2006) has set the clean-up threshold for brownfield sites as $270 \mathrm{mg} \cdot \mathrm{kg}^{-1}$ for soil copper levels.

Understanding the use and accumulation of copper in agricultural soils is a necessary component of land management for agricultural producers. A research summary by the New Jersey Department of Environmental Protection (1993) found that rural New Jersey soils had a geometric mean of $4.8 \mathrm{mg} \cdot \mathrm{kg}^{-1}$ of total copper. Crop uptake of copper can vary by species and cultivar, is impacted by soil factors, and is typically absorbed into the roots of crops but less so into the shoots (Marschner, 1995). Copper can be translocated into the shoots and leaves in high numbers when soil copper levels are excessive,

\begin{tabular}{llll}
\hline $\begin{array}{l}\text { Units } \\
\text { To convert U.S. to SI, } \\
\text { multiply by }\end{array}$ & U.S. unit & SI unit & $\begin{array}{l}\text { To convert SI to U.S., } \\
\text { multiply by }\end{array}$ \\
\hline 2.54 & inch(es) & $\mathrm{cm}$ & 0.3937 \\
25.4 & inch(es) & $\mathrm{mm}$ & 0.0394 \\
1.1209 & $\mathrm{lb} / \mathrm{acre}$ & $\mathrm{kg} \cdot \mathrm{ha}^{-1}$ & 0.8922 \\
28.3495 & $\mathrm{oz}$ & $\mathrm{g}$ & 0.0353 \\
1 & $\mathrm{ppm}$ & $\mathrm{mg} \cdot \mathrm{kg}^{-1}$ & 1 \\
$\left({ }^{\circ} \mathrm{F}-32\right) \div 1.8$ & ${ }^{\circ} \mathrm{F}$ & ${ }^{\circ} \mathrm{C}$ & $\left({ }^{\circ} \mathrm{C} \times 1.8\right)+32$
\end{tabular}


Table 1. Copper fungicide application rates for tomato crops according to three commonly used product label instructions.

\begin{tabular}{lcc}
\hline Product & $\begin{array}{c}\text { Minimum metallic copper } \\
\text { element per application } \\
(\text { lb/acre })^{\mathrm{z}}\end{array}$ & $\begin{array}{c}\text { Annual maximum metallic copper element } \\
\text { application rate as per product label }\end{array}$ \\
\hline $\begin{array}{l}\text { Copper } \\
\text { hydroxide } 76.77 \%\end{array}$ & 1.6 & Up to $8 \mathrm{lb} /$ acre per year \\
$\begin{array}{l}\text { Copper } \\
\text { hydroxide } 77 \%\end{array}$ & 1 & Up to $8 \mathrm{lb} /$ acre per year \\
$\begin{array}{l}\text { Cuprous } \\
\text { oxide } 83.9 \%\end{array}$ & 0.94 & $\begin{array}{l}1.88 \mathrm{lb} / \text { acre per application }=30.1 \mathrm{lb} / \text { acre over } \\
\text { a } 16 \text {-week spray period }(\text { no stated maximum } \\
\text { application) }\end{array}$ \\
\hline
\end{tabular}

${ }^{\mathrm{z}} 1 \mathrm{lb} / \mathrm{acre}=1.1209 \mathrm{~kg} \cdot \mathrm{ha}^{-1}$.

and the uptake of copper by the plants can be impacted by soil phosphorus deficiencies (Lange et al., 2017; Verdejo et al., 2016). When the copper level in plant tissue is $\geq 19 \mathrm{mg} \cdot \mathrm{kg}^{-1}$ dry weight, it is considered toxic (Davis and Beckett, 1978).

Growers have expressed concerns about soil copper levels and their impact on soil bacteria and human health. A 2016 study evaluated grassland soils that had been subjected to centurylong exposure to normal $(\approx 15$ $\left.\mathrm{mg} \cdot \mathrm{kg}^{-1}\right)$, high $\left(\approx 450 \mathrm{mg} \cdot \mathrm{kg}^{-1}\right)$, and extremely high $\left(\approx 4500 \mathrm{mg} \cdot \mathrm{kg}^{-1}\right)$ copper levels (Nunes et al., 2016). The study results showed a decline in bacterial biomass and fungal biomass with increasing concentrations of copper compounds over time (Nunes et al., 2016). Because more urban and industrial sites are being used for the production of food and outdoor spaces in communities, research involving the impact of heavy metals on soil health will continue to be a priority.

Copper uptake from the soil by plants can vary depending on the crop and can impact the total and available copper in the soil. An evaluation of the accumulation of copper in six commonly grown vegetables found considerable variations according to the cultivar of carrot (Daucus carota), spinach (Spinacia oleracea), and pea (Pisum sativum) (Alexander et al., 2006). A University of Idaho study evaluated copper uptake by potato (Solanum tuberosum) to determine soil copper thresholds for potato production (Moore et al., 2013). Silt loam and sandy soils were amended with a copper rate of $100 \mathrm{mg} \cdot \mathrm{kg}^{-1}$ of copper and produced potato shoots and roots that had removed $2 \mathrm{lb} /$ acre of copper in a silt loam soil and potato shoots that had removed $6.6 \mathrm{lb} /$ acre copper in a sand soil (Moore et al., 2013). A study performed in New
Jersey showed that sweet corn $(Z$. mays) fresh market ears removed $0.014 \mathrm{lb} /$ acre of copper from a silt loam soil (Heckman, 2007). Calculations of soil additions and removal can be complicated for diversified farming situations when an abundance of crop species and cultivars are grown on relatively small acreages with complex crop rotations.

The objectives of this study were to evaluate the use of three commonly used copper fungicides on 15 farms and the resulting soil copper levels and to assess the impacts of these copper levels on lettuce (Lactuca sativa) grown in the sampled soils in a greenhouse study. The gathered information was used to determine if copper levels had changed on individual farms over time and if these levels are excessive enough to cause phytotoxicity in lettuce. This information has been used to recommend best practices for farms using copper-based fungicides. Collectively, the information gathered and current best management practices can assist growers in making more informed decisions about copper fungicide use on their farms.

\section{Materials and methods}

Ten certified organic farms and five conventional farms were surveyed for soil copper levels. Sampled farms represented seven different soil series in the New Jersey Piedmont and Coastal Plain physiographic provinces, and soil samples had an average mean soil $\mathrm{pH}$ of 6.44 , with a low of 5.7 and a high of 7.0. These soil $\mathrm{pH}$ levels represent a range that allows for reduced copper availability (U.S. Department of Agriculture, 2000). Among the population of farms used in this study, all had at least one application of copper-based fungicides during the previous 2 years. Copper-based fungicides were used on 13 of the 15 farms during the 2013 sampling season. If copper was not used at the farm during the 2013 growing season, then soil samples were taken from soils that had copper-based fungicides applied in 2012. The noncopper-applied sampling location was verbally identified by the grower as an area where copper had not been applied according to their historical knowledge of the area. Nonspray sampling locations included fallow fields, fields planted in cover crops, fence rows, and adjacent woodlands.

Farm soils were sampled by using a heavy-duty stainless-steel soil probe with a foot stand and hand plunger. A minimum of 16 cores (diameter, 2.25 $\mathrm{cm})$ were pulled from the soil in a random pattern throughout the field area and mixed in sealable plastic bags marked with a unique identifier and the sampling date. Soil samples were collected during Fall 2013 from a depth of 0 to 6 inches. The bags were placed into a transportation bin; they were kept open so that the soil would begin to dry. Soil samples were taken to the Rutgers Soil Testing Laboratory after a drying period of 2 weeks at room temperature.

At the Rutgers Soil Testing Laboratory, soil samples were air-dried and ground using a soil grinder (Dynacrush; Custom Laboratory Equipment, Orange City, FL). They were sieved using a number 10 mesh 2 -mm sieve according to standard processing methods. Samples were tested for soil $\mathrm{pH}$ using a 1:1 volume soil:deionized water ratio and an electronic $\mathrm{pH}$ meter (Seven Excellence; Mettler, Toledo, $\mathrm{OH}$ ) (Mclean, 1982). The buffering capacity of the soil was also quantified to determine liming rates using the AdamsEvans buffer method (Adams and Evans, 1962). Nutrient levels (phosphorus, potassium, calcium, magnesium, 
Table 2. Mean comparison of copper-applied and noncopper-applied soil samples, lettuce leaf uptake, and lettuce head weight from New Jersey farm soils.

\begin{tabular}{|c|c|c|c|c|}
\hline Treatment & $\begin{array}{l}\text { Total soil copper } \\
\left(\mathrm{mg} \cdot \mathrm{kg}^{-1}\right)^{\mathrm{z}}\end{array}$ & $\begin{array}{c}\text { Soluble soil copper } \\
\left(\mathrm{mg} \cdot \mathrm{kg}^{-1}\right)\end{array}$ & $\begin{array}{c}\text { Lettuce leaf tissue } \\
\text { copper } \\
\left(\mathrm{mg} \cdot \mathrm{kg}^{-1}\right)\end{array}$ & $\begin{array}{l}\text { Lettuce } \\
\text { head wt } \\
(\mathrm{g})^{\mathrm{z}}\end{array}$ \\
\hline Nonapplied & 10.2 & 2.9 & 19.6 & 14.7 \\
\hline$P$ & $\mathrm{NS}^{\mathrm{y}}$ & $* *$ & NS & * \\
\hline
\end{tabular}

Table 3. Summary of copper-applied and noncopper-applied soils samples from 15 New Jersey farms.

\begin{tabular}{|c|c|c|c|c|c|c|c|c|c|c|}
\hline \multirow[b]{2}{*}{$\begin{array}{l}\text { Farm } \\
\text { no. }\end{array}$} & \multicolumn{2}{|c|}{$\begin{array}{l}\text { Soil organic } \\
\text { matter }(\%)^{z}\end{array}$} & \multicolumn{2}{|c|}{ Soil pH } & \multicolumn{2}{|c|}{$\begin{array}{l}\text { Total soil copper } \\
\left(\mathrm{mg} \cdot \mathrm{kg}^{-1}\right)^{\mathrm{y}}\end{array}$} & \multicolumn{2}{|c|}{$\begin{array}{l}\text { Soluble soil copper } \\
\left(\mathbf{m g} \cdot \mathrm{kg}^{-1}\right)^{\mathrm{x}}\end{array}$} & \multicolumn{2}{|c|}{$\begin{array}{c}\mathrm{CO}_{2} \text { burst test } \\
\left(\mathrm{mg} \cdot \mathrm{kg}^{-1}\right)^{\mathrm{w}}\end{array}$} \\
\hline & $\begin{array}{l}\text { Copper } \\
\text { applied }\end{array}$ & $\begin{array}{l}\text { Noncopper } \\
\text { applied }\end{array}$ & $\begin{array}{l}\text { Copper } \\
\text { applied }\end{array}$ & $\begin{array}{c}\text { Noncopper } \\
\text { applied }\end{array}$ & $\begin{array}{l}\text { Copper } \\
\text { applied }\end{array}$ & $\begin{array}{c}\text { Noncopper } \\
\text { applied }\end{array}$ & $\begin{array}{l}\text { Copper } \\
\text { applied }\end{array}$ & $\begin{array}{c}\text { Noncopper } \\
\text { applied }\end{array}$ & $\begin{array}{l}\text { Copper } \\
\text { applied }\end{array}$ & $\begin{array}{l}\text { Noncopper } \\
\text { applied }\end{array}$ \\
\hline 2 & 2 & 1 & 6.0 & 6.4 & 13.5 & 17.5 & 8.4 & 7.5 & 6 & 6 \\
\hline 3 & 2 & 5 & 6.5 & 4.2 & 17.5 & $<10$ & 3.8 & 1.4 & & \\
\hline 6 & 1 & 2 & 6.6 & 6.7 & 11.0 & 12.0 & 2.2 & 1.4 & & \\
\hline 7 & 4 & 3 & 6.1 & 6.0 & 35.5 & 21.0 & 9.0 & 3.8 & & \\
\hline 8 & 6 & 4 & 6.7 & 6.1 & 20.5 & 14.5 & 4.2 & 3.1 & & \\
\hline 9 & 4 & 5 & 6.7 & 7.1 & 22.5 & $<10$ & 9.5 & 3.9 & & \\
\hline 10 & 3 & 3 & 6.3 & 6.5 & 26.0 & 12.0 & 7.5 & 2.3 & & \\
\hline 11 & 3 & 4 & 6.8 & 5.9 & 48.5 & 13.5 & 17.1 & 2.8 & & \\
\hline 15 & 4 & 4 & 7.0 & 6.8 & 153.0 & 20.5 & 14.2 & 2.9 & 78 & 72 \\
\hline
\end{tabular}

${ }^{\mathrm{z}}$ Evaluated with organic carbon analysis.

${ }^{y}$ Assessed with X-ray fluorescence spectroscopy; $1 \mathrm{mg} \cdot \mathrm{kg}^{-1}=1 \mathrm{ppm}$.

${ }^{x}$ Assessed with Mehlich-3 extraction.

${ }^{\mathrm{w}}$ Carbon dioxide burst test used when crop and noncrop sample soils from the same farm had similar $\mathrm{pH}$ and fertility; low activity range $=0-20 \mathrm{mg} \cdot \mathrm{kg}^{-1}$, medium $=20-60$ $\mathrm{mg} \cdot \mathrm{kg}^{-1}$, high $=60-120 \mathrm{mg} \cdot \mathrm{kg}^{-1}$.

copper, manganese, zinc, boron, and iron) were evaluated using extraction with Mehlich-3 solution (Mehlich, 1984) and subsequent analysis by atomic emission using an inductively coupled plasma spectrometer (radial iCAP 6300; Thermo Fisher Scientific, Waltham, MA).

Total soil copper levels were evaluated by soil scientists at the USDA Natural Resource Conservation New Jersey state office using a portable X-ray fluorescence spectroscopy device (Delta XRF; Olympus, Center Valley, PA). The X-ray fluorescence spectroscopy device (XRF) is a handheld X-ray fluorescence meter. This screening device evaluates total milligrams per kilogram of specific metals in soil, and it is used by placing the analyzer directly on the soil according to the guidelines of the U.S. Environmental Protection Agency (2007).
Following the analysis of the soil by Mehlich-3 extraction and by XRF, soil samples were used in a lettuce trial at the FMC Innovation Center greenhouses in Ewing, NJ. Lettuce was chosen due to its sensitivity to metal toxicity, including copper, according to the Organization for Economic Cooperation and Development (OECD, 2006). Farm soils were placed into 3inch square plastic greenhouse pots and identified by farm number with four lettuce plants per farm soil. 'Red Fire' lettuce, provided by Stokes Seed (Buffalo, NY), was planted in each of the pots and allowed to grow in a greenhouse setting for $58 \mathrm{~d}$. Fertilization of nitrogen $(\mathrm{N})$, phosphorus $(\mathrm{P})$, and potassium $(\mathrm{K})$ occurred using a $20 \mathrm{~N}-$ 4.4P-16.6K fertilizer mixture to deliver $\mathrm{N}$ at 150 ppm through drip irrigation. Copper was $0.0125 \%$ of the fertilizer mixture that was delivered at
$9.3 \times 10^{-6} \mathrm{ppm}$. The edible portion of the lettuce was harvested by cutting the plant 0.5 inches above soil level; care was taken to not contaminate the lettuce leaves with soil. Each plant was weighed and photographed. Specimens were dried using a laboratory oven at $70{ }^{\circ} \mathrm{F}$ for $48 \mathrm{~h}$ before being ground in a plant tissue grinder. Samples were packaged in plastic specimen tubes, labeled with the farm number, and sent to Brookside Laboratory (New Knoxville, $\mathrm{OH}$ ) for tissue analysis to determine the amount copper in leaves. The ground plant sample was digested with nitric acid and hydrogen peroxide in a microwave (MARS 6; CEM, Matthews, NC). After digestion, the solution was analyzed through an inductively coupled plasma optical emission spectrometry analyzer (6100 Duo-ICP; Thermo Fisher Scientific) for mineral concentrations. 


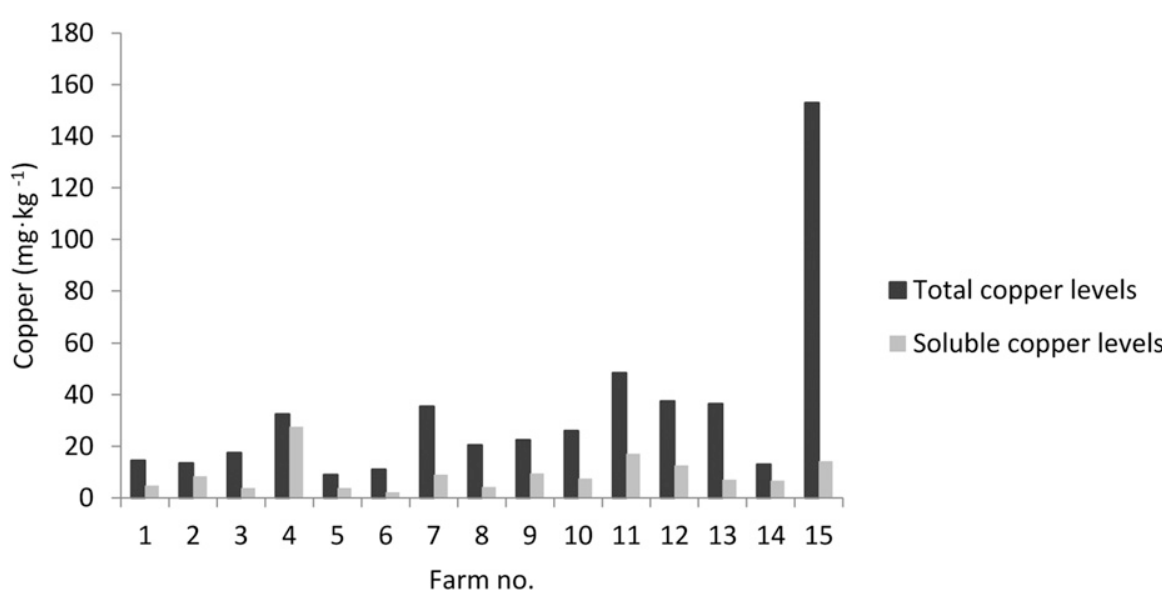

Fig. 1. Effects of spraying copper fungicides on crop soils shown as differences in total and soluble soil copper level variations by farm. Pairs showed significant differences $(P \leq 0.05)$ according to the $t$ test analysis of copper-applied soils; 1 $\mathrm{mg} \cdot \mathrm{kg}^{-1}=1 \mathrm{ppm}$.

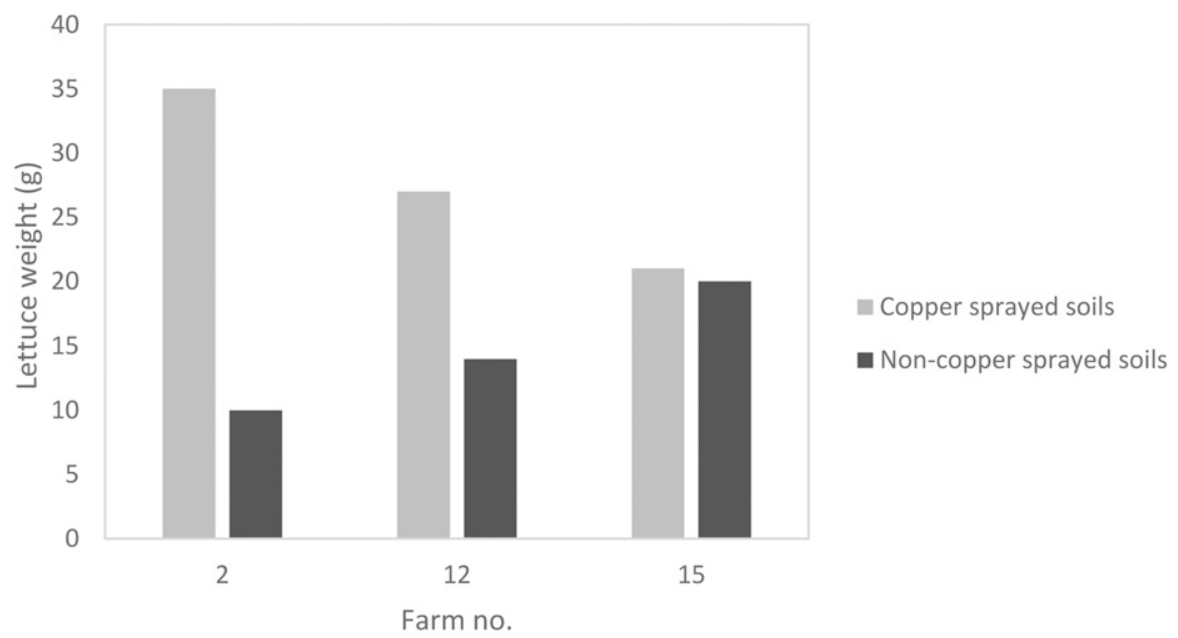

Fig. 2. Lettuce head weight based on farm locations where $\mathrm{pH}$ and soil fertility in both copper-applied and noncopper-applied soils were similar. Pairs showed significant differences in growth $(P \leq 0.05)$ according to the $t$ test analysis; $1 \mathrm{~g}=$ $0.0353 \mathrm{oz}$.

To address growers concerns about soil copper levels impacting microbial activity in the soil, a carbon dioxide $\left(\mathrm{CO}_{2}\right)$ burst test (Solvita; Woods End Laboratory, Mt. Vernon, ME) was used. The $\mathrm{CO}_{2}$ burst test measures respiration as an indication of soil quality through microbial activity. This test was used for sampled soils where both the copperapplied and noncopper-applied area had similar $\mathrm{pH}$ and overall fertility using the guidelines at the time (Brinton, 2013).

During the statistical analysis, the copper-applied and noncopper-applied soil sample areas represented pairs of treatments. Therefore, the collected data were analyzed as a randomized complete block with 15 treatments. Statistical analysis software (Minitab 19; Minitab, State College, PA) was used to conduct a $t$ test to determine the significance of the values of the copper-applied soils in relation to the noncopper-applied soils and the impact on greenhouse-grown lettuce head weight.

\section{Results}

Copper fungicide use was wideranging, varying from one-spray application during the previous year to more than 30 years of historical use, regardless of certified organic or conventional practices used on each farm. Farms surveyed for this study applied copper fungicide as frequently as every $7 \mathrm{~d}$ when disease forecasting models indicated that it was necessary. The highest level of copper found on one farm was $153 \mathrm{mg} \cdot \mathrm{kg}^{-1}$ total copper, which was assessed with the XRF scanner; this was lower than the 270 $\mathrm{mg} \cdot \mathrm{kg}^{-1}$ threshold for clean-up set by New York State. This farm had a soluble copper rate of $14.17 \mathrm{mg} \cdot \mathrm{kg}^{-1}$, which was higher than the estimated average for New Jersey soils but within the range of normal that others studies have used. Total soil copper content, as measured by the XRF, was, on average, more than three-times greater in copper-applied areas compared with noncopper-applied areas (Table 2). Mehlich-3 soil fertility test extract levels of copper were about three-times greater in copper-applied soil areas. It is apparent that the Mehlich-3 soil test extracted only approximately one-third of the total soil copper, indicating that one-third of the total copper was available to plants in the soil (Table 2). Results of the lettuce leaf and shoot analysis to determine the copper uptake were not significantly different when grown in copper-applied soils compared with noncopper-applied soils (Table 2). Growers who use only Mehlich-3 soil fertility tests need to be aware that total soil copper levels might be exponentially higher than the available soil copper levels. Comparisons of the noncopper-applied soils and copperapplied soils have indicated that soil copper levels have increased over time due to the use of copper fungicides for successful crop production (Table 3 , Fig. 1).

Lettuce plants did not exhibit any visual signs of toxicity, such as lack of vigor or reduced root development, when grown in the 15 farm samples. For 12 of the 15 paired soils, soil samples from areas where copper was applied had a significantly greater dry matter weight when compared with soils that did not have copper applied to them. Noncopper-applied areas that were not in a production rotation, and therefore were not improved, had lower head weights (Fig. 2). A leaf tissue analysis found no significant difference in copper concentrations in lettuce plants grown on copper-applied soils compared with noncopper-applied area soils (Table $2)$. There was a significant difference in the lettuce head weight when grown in copper-applied soils with similar soil $\mathrm{pH}$ and fertility when compared with noncopper-applied 
soils (Table 2, Fig. 2), and the head weight increased in soils where copper was applied.

The $\mathrm{CO}_{2}$ burst test results were most directly impacted by the soil organic matter content levels. Soils with less than $2 \%$ soil organic matter had very low $\mathrm{CO}_{2}$ burst responses. Soils with $3 \%$ or greater soil organic matter content had higher $\mathrm{CO}_{2}$ burst responses. One farm had a $2 \%$ difference in organic matter content between the copper-applied soil and the noncopperapplied soil, and there was a reduced $\mathrm{CO}_{2}$ burst response in the soil with the lower organic matter content (Table 3 ). The $\mathrm{CO}_{2}$ burst test showed that there was microbial activity in all of the soils tested, and that increased organic matter content was correlated with an increase in the amount of respiration by the microbial community (Table 3 ).

\section{Conclusions and recommendations}

Based on the absence of visible injury, lettuce head weight reduction, and difference in leaf tissue copper concentration, we found no evidence to suggest that soil copper concentration reached a phytotoxic level for the lettuce crop. At this point, the use of copper fungicides is not limiting lettuce growth on any of the farm soils sampled. Nevertheless, because crop uptake and removal of copper is very small, and because the potential for copper toxicity may become a future concern, organic and conventional growers should follow best management practices when using copperbased fungicides. Certain practices are recommended for those using copper-based fungicides: 1) Carefully read the copper pesticide product label and follow all directions. 2) Certified organic producers should verify that that the product is listed in their organic system plan, and that the product is approved by the certifier. 3) Organic growers are encouraged to use all available cultural practices as an alternative or to supplement the use of copper fungicides. 4) Crop rotations should be used to minimize multiple-year copper applications to fields. 5) Copper-based fungicides, to be effectively preventative, must be applied before infection. 6) Rainfall should be tracked and totals should be used when deciding whether to use repeat sprays due to rainfall removal of the product $(<1$ inch of rain does not warrant reapplication; with 1 to 2 inches of rain, the spray interval can be reduced by half; and $>2$ inches of rain warrants a full reapplication). 7) Care should be taken to spray only the foliage of the target crop and minimize ground spraying of copper. 8) Total and available soil copper levels and soil $\mathrm{pH}$ should be monitored regularly through a reliable soil testing laboratory. 9) Growers should be mindful of animal manures and other sources that may serve as additional copper inputs.

\section{Literature cited}

Adams, F. and C.E. Evans. 1962. A rapid method for measuring lime requirement of red-yellow soils. Proc. Soil Sci. Soc. Amer. 26:355-357.

Alexander, P.D., B.J. Alloway, and A.M. Dourado. 2006. Genotypic variations in the accumulation of $\mathrm{Cd}, \mathrm{Cu}, \mathrm{Pb}$, and $\mathrm{Zn}$ exhibited by six commonly grown vegetables. Environ. Pollut. 144:736-745.

Ashjaei, S., W. Miller, M. Cabrera, and M. Hassan. 2011. Arsenic in soils and forages from poultry litter amended pastures. Intl. J. Environ. Res. Public Health 8:1534-1546.

Brinton, W. 2013. Soil $\mathrm{CO}_{2}$ respiration test: Official Solvita guideline. Version 2013/2. Woods End Lab, Mount Vernon, ME.

Davis, R.D. and P.H.T. Beckett. 1978. Upper critical levels of toxic elements in plants. New Phytol. 80:23-32.

Evans, I., E. Solberg, and D. Huber. 2007. Mineral nutrition and plant disease. APS Press, St. Paul, MN.

He, Z., D. Endale, H. Schomberg, and M. Jenkins. 2009. Total phosphorus, zinc, copper, and manganese concentrations in Cecil soil through 10-years of poultry litter application. Soil Sci. 174:687-695.

Heckman, J. 2007. Sweet corn nutrient uptake and removal. HortTechnology 17:82-86.

Lange, B., A. Van der Ent, G. Baker, G. Echevarria, F. Mahy, P. Malaisse, O. Meerts, N. Pourret, M. Verbruggen, and M. Faucon. 2017. Copper and cobalt accumulation in plants: A critical assessment of the current state of knowledge. New Phytol. 213:537-551.

Marschner, H. 1995. Mineral nutrition of higher plants. 2nd ed. Academic Press, San Diego, CA.
Mclean, E.O. 1982. Soil pH and lime requirement, p. 199-224. In: A.L. Page (ed.). Methods of soil analysis. Part 2. Chemical and microbiological properties. Amer. Soc. Agron., Madison, WI.

Mehlich, A. 1984. Mehlich 3 soil test extractant: A modification of the Mehlich 2 extractant. Commun. Soil Sci. Plant Anal. 15:1409-1416.

Moore, A., M. Satterwhite, and J. Ippolito. 2013. Soil copper thresholds for potato production. Western Nutrient Mgt. Conf. Proc. 10:152-155.

National Research Council. 1994. Nutrient requirements of poultry. 9th ed. Natl. Acad. Press, Washington, DC.

New Jersey Department of Environmental Protection. 1993. A Summary of selected soil constituents and contaminants at background locations in New Jersey. 20 Jan. 2020. <https://www.state.nj.us/ $\mathrm{dep} / \mathrm{dsr} /$ soilrep.pdf>.

New York Department of Environmental Conservation and New York State Department of Health. 2006. New York State Brownfield Cleanup Program, development of soil cleanup objectives technical support document. New York Department of Environmental Conservation and New York State Department of Health, Albany.

Nunes, I., S. Jacquiod, A. Brejnrod, P. Holm, A. Johansen, K. Brandt, A. Prieme, and S. Sorensen. 2016. Coping with copper: Legacy effect of copper potential activity of soil bacteria following a century of exposure. FEMS Microbiol. Ecol. 92:fiw175.

Organization for Economic Cooperation and Development. 2006. Test 208: Terrestrial plant test: Seedling emergence and seedling growth test. Guidelines for the testing of chemicals, Section 2. Organization for Economic Cooperation and Development, Paris, France.

U.S. Department of Agriculture. 2000. Soil quality - urban technical note number 3: Heavy metal soil contamination. 20 Jan. 2020. <https://www.nrcs.usda. gov/Internet/FSE_DOCUMENTS/ nrcs142p2_053279.pdf>.

U.S. Environmental Protection Agency. 2007. Method 6200: Field portable x-ray fluorescence spectrometry for the determination of elemental concentrations in soil and sediment. 20 Jan. 2020. <https:// www.epa.gov/sites/production/files/ 2015-12/documents/6200.pdf>.

Verdejo, J., R. Ginocchio, S. Sauve, P. Mondaca, and A. Neaman. 2016. Thresholds of copper toxicity to lettuce in fieldcollected agricultural soils exposed to copper mining activities in Chile. J. Soil Sci. Plant Nutr. 16:154-158. 